\title{
Financial Markets are Not Efficient: Financial Literacy as an Effective Risk Management Tool
}

\author{
Costas Siriopoulos \\ College of Business, Zayed University, Abu Dhabi, United Arab Emirates \\ *Correspondence: Costas Siriopoulos, Email: konstantinos.Syriopoulos@zu.ac.ae, ORCID ID: 0000-0003-1368-7182
}

\begin{abstract}
This paper advances the view that the deep confidence of market regulators in the assumptions and premises of the Efficient Market Hypothesis (EMH) has led to the underestimation of market risks, thus inactivating the market education of existing and future investors. Hence, they have not responded to financial illiteracy, which exacerbated the recent financial crisis. Investor education may be considered as a systemic risk management tool for future financial crises and, especially, financial literacy can drive a wedge between the regulation and the prevention of severe financial crises based on expected benefits versus losses. This also will help to regain investors' trust in the market after the crisis and instill investors with more confidence. This approach has not yet received the attention it deserves.
\end{abstract}

Keywords: Efficient market hypothesis, Financial literacy, Financial crisis, Financial regulation, Financial innovation, Systemic risk

JEL Classification: G01, G14, G18, G53

\section{ARTICLE INFORMATION}

Author(s): Costas Siriopoulos

Received: 21 Jan, 2021; Accepted: 22 Feb, 2021; Published: 05 Mar, 2021 ;

e-ISSN: 2347-4696;

Paper Id: BMN-IJBMR-2021-18;

Citation: doi.org/10.37391/IJBMR.090110

Webpage-link:

https://ijbmr.forexjournal.co.in/archive/volume-9/ijbmr-090110.html

\section{INTRODUCTION}

Two decades ago, we began to witness the largest financial crisis in practically a century, incurring losses for economies, investors, funds, borrowers and lenders. The harshness of the recent financial turmoil has forced investors, academics, regulators and policymakers to reconsider the nexus of financial markets, revisit the role and functions of financial intermediaries and institutions, and reexamine the regulatory architecture across the markets. Most studies have viewed the crisis first as a regulatory failure and raised serious questions about the validity of the efficient market hypothesis (EMH) and about the rationality of investors' decision making. EMH was developed independently by P. Samuelson, and E. Fama, in the mid-1960s and since then has received an abundance of attention. Hence, this is an auspicious time to revisit the theory of efficient markets and its implications for financial regulation and public policy. Analyzing regulators' belief in EMH during recent financial crisis is relevant for a number of reasons. First, it offers insights into assessing the role of EMH in explaining the crisis matters for its failure in detecting bubbles in assets prices $[1,2]$. The degree of anchoring to $\mathrm{EMH}$ of regulators and investors is thus likely to affect both the depth and severity of crisis and guide financial architecture accordingly [3, 4]. Second, the financial crisis and its implications constitute an on-going challenge for contemporary mainstream economics, as severe financial events do not match with basic economic theories [5]. Although no longer new to the academy, revisiting this framework is particularly appropriate because we are now experiencing a re-evaluation of the efficiency of the financial system supported by a growing number of applied financial studies in both developed and emerging capital markets that have provided evidence against market efficiency. Brown [6] in his excellent paper, analyzed the empirical findings of EMH and its practical and intellectual implications for the last 75 years. In other words last decades, showed a paradigm shift from rational expectation and investors' homogeneity to an alternative, where economic agents are heterogeneous and boundedly rational. Finally, the recent financial crisis demonstrated the critical importance of financial literacy and investor education both for the economic welfare of households and for the stability of the financial system as a whole $[7,8]$.

This paper advances the view that the deep confidence of market regulators in the EMH has led to the underestimation of market risks, thus inactivating the education of existing and future investors, i.e. they have not responded to financial illiteracy, which exacerbated the crisis. There is also a paradox here, namely that while technology increases the accessibility of the average investor to the markets and to the majority of financial instruments, financial illiteracy also increases [9] although the opposite should hold. That is a positive relationship between the increased financial innovation with the need for the general society to be knowledgeable about those financial products [10]. This in combination with the complexity of financial instruments leads to increased difficulty of pricing and interpretation is in the core of future financial crisis. In this paper, we examine the implications of the efficient market hypothesis and its role in financial crises given financially illiterate investors and ad hoc regulatory solutions.

The many references by regulators and academics $[4,11,12]$ combined with the rapid deregulation of markets, the development of financial innovation and the increase in 
leverage, have resulted in the development of so-called "grey" areas in financial markets that is, where the supervisory mechanism has not been adequate and led to the last crisis with greater ease and speed than before. Regulators failed in at least three ways, in that they (i) were indifferent to the excessive profits of these markets, as they believed that market prices discount all available information and thus, are good signals of rationally assessed real value of firms, (ii) underestimated the subsequent risks as predicted by their statistical models under normality assumptions, and (iii) overestimated market discipline as an effective tool in reducing risk. As a result, regulators were inactive and submissive to the hegemony of the EMH, believing that the markets would exhibit efficiency and would find their equilibrium.

But instead of believing that markets are efficient under the strict assumptions of rational expectations (the EMH) which implies that investors are aware of the nature and risks of the financial products, it would be safer to assume that markets are more "in love" with extremes (Minsky's hypothesis), that returns are characterized by long-term memory (characteristic of chaotic markets), and that the occurrence of the next crisis is highly probable. The speed of price adjustment in new information is the key factor for long-memory asset returns against market efficiency. However, this process is not only concerned with the collection of information, not even the management of new data and evidence. The fundamental understanding of information and its basic interpretation is the first-order concern in the ability to make informed decisions and effective choices regarding the use and management of investment alternatives. However, it is often the case that not all groups in society have the necessary literacy to understand information about different financial products, which may be vital for their financial wellbeing [13] and contribute most to overall happiness compared to satisfaction in family, health and work domain [14].

Although financial literacy becomes increasingly common and of growing importance, very few is recognizing its role as a systemic risk management tool. For instance, many studies $[15,16]$ found that people do not understand even the basic terms in a financial contract. Barber, et al. [17] reported that most investors have no the required education to choose a mutual fund that fits their needs as they have no formal training to understand the factors affecting the performance, the risks, and the diversification benefits of such a product. Also, Siriopoulos and Skaperda [18] offered evidence that investors in US mutual fund industry pay higher fees for the same return. Blue and Brimble [19] presented the importance of embedding financial literacy education into primary and secondary school curriculums.

In particular, regulators now understand that markets and investors may not have the training and the experience to address the risks posed by complex market conditions and products and therefore systematically underestimate these risks. Then, if so, an effective way to deal with this is for there to be synergies and complementarity: active regulators, systematic education of economic agents, compliance training and financial literacy, together representing a convex strategy. A convex payoff function is expressed in the difference between possible gains and losses. Thus, investor education may be considered as a systemic risk management tool for future financial crises; in particular, financial literacy can drive a wedge between the regulation and the prevention of severe financial crises based on expected benefits versus losses. This also will help to regain investors' trust in the market after the crisis and deliver investors with more confidence. This approach has not yet received the attention it deserves.

The basic methodological feature of this paper is the logical analysis. We first question the hegemony of the EMH, and we report on its failure. Second, we investigate its role in the recent financial crisis and the witness of regulators. Third, we analyze the complementarity of regulators and financial education as a systemic risk management tool. These questions operate on different levels, with the second and third question aiming for illustrating general developments regarding the role that financial literacy might have in a future financial crisis. The first question, on the other hand, focuses on the failure of the mainstream paradigm and its fundamental cause that is the mechanisms of the capitalistic system and the limitations of its ongoing financialization.

The aim of this paper is to gain a better understanding of the impact of the Efficient Market Hypothesis and its rational expectations corollary on the financial crisis. For this purpose, the paper contextualizes the role and effects of EMH in the financial crisis and contributes to the debate on financial literacy and financial market risk. The role of EMH and its implications aftermath the recent financial crisis from a regulators' point of view is discussed and analyzed within the discourses on ideology in curriculum design.

The structure of the paper is as follows. The next section reviews the literature under the hegemony of the EMH, its limited and incomplete description of financial markets' behaviour, and its role in the recent financial crisis. Section 2 generalizes the main observations and discusses the complementarity between regulation and financial education. In section 3 we discuss why programs on investor education and financial literacy should be comprehensive, and not limited to the mainstream financial economics. This discussion argues that a combination of regulators and financial education can be viewed as a risk management tool that may be used when high uncertainty is present. This will result in improvements in the markets, financial innovation and intermediation, and benefits for society as a whole. The last section summarizes the discussion and concludes the paper.

\section{LITERATURE REVIEW}

For advocates of the mainstream doctrine, the EMH is not the cause of a crisis and asset bubble, but it is only a (limited and incomplete) description of how financial asset prices behave over time. Nevertheless, for the information to be fully reflected in the current price levels, as required by the EMH, knowledge regarding investors' risk attitude and management 
of the bulk of information is needed. Therefore, the EMH implicitly assumes that investors are financially literate in that they are able to collect relevant information, understand and manage it.

\subsection{The Hegemony of the EMH in the Last 60 Years, and its Failure}

Paul Samuelson and Eugene Fama advanced in parallel their hypothesis regarding market efficiency, but their contribution lies in the different "expertise" developed by each author. Samuelson offered a political and institutional expertise useful to policymakers and the social benefit of speculation, while Fama made practical recommendations for investors [20]. Their comparative contribution is important because each of these two views have changed financial theory, policy response and investment practice, and their assumptions have guided financial markets' regulators and driven financial education.

Sharpe [21] postulated that the efficiency of the capital markets is "self-evident to most professional economists" (p. 418) and Beaver [22] considered the EMH a triviality. However, what makes the EMH non-trivial is the inability of traders to assimilate the costly available information due to their financial illiteracy. Since, because even if all information were available at a low cost one cannot assume that all traders are sufficiently skillful to interpret and manage the bulk of data and evidence. In the same route Jensen [23] declared that "there is no other proposition in economics which has more solid empirical evidence supporting it than the Efficient Market Hypothesis".

Conventional investment theory under the hegemony of the $\mathrm{EMH}$, posits that in competitive financial markets asset prices reflect the dispersed information that is relevant to assets' value, and thus, market prices are aggregators of the publicly available information in the market. Therefore, no investor is able to beat the market and earn abnormal profits, above the average market returns at least in theory. But as Thaler and Sustain [24] noted, "if you look at economics textbooks, you will learn that homo economics can think like Albert Einstein, store as much memory as IBM's Big Blue, and exercise the willpower of Mahatma Gandhi". One could add that economic agents infer much like as an expert system. This is partly because after Fama's formulation of the EMH and Samuelson's subsequent martingale presentation of it, most textbooks in capital markets have blindly accepted this theoretical framework of financial markets. As a consequence, regulators have adopted and followed the EMH axiomatically.

This means that the rational investor is able to manage all available information, and in this sense, the market is considered to be a process of seeking equilibrium. This equilibrium is optimal (Nash equilibrium), and if investors optimize their decisions, then it is possible to reach it. However, the dynamics, volatility, and complexity of markets as well as investors' behaviour do not allow for the optimization of investment decisions. Thus, the ability of investors to make decisions under rational expectations, no matter how important they are to market stability that could lead to information efficiency, cannot be put into practice.

Many empirical studies using every possible statistical technique and econometric modelling approach, have proved that financial markets are not efficient. From simple autocorrelation tests [25] to calendar anomalies [26, 27], and non-linear tests and long memory effects [28, 29] there is ample evidence against market efficiency across different time periods [30] and market characteristics. Supporters of the EMH wonder "how bubbles could have happened before the words "efficient market" were first set in print" [2], although the first bubble was known since 1637 (the Dutch "tulip mania") and many others have followed, up to 1929.

Regarding the implications of the efficient market hypothesis in the financial crisis, Subramanian [11] summarizes the theoretical criticism raised by regulators and renowned academics. This criticism included comments by A. Turner, chairman of the UK's Financial Market Authority, who stated, "market efficiency does not imply rationality, individual rationality does not ensure collective rationality, ... empirical evidence illustrates large-scale herd effects and market overshoots", R. Shiller, Nobel Prize in Economics 2013 who wrote, "the efficient market hypothesis is one of the most egregious errors in the history of economic thought", and J. Stiglitz, Nobel Prize in Economics 2001, who stated, "the idea behind the efficient market hypothesis is very powerful but wrong". Still, Krugman [12] considered this way of understanding the market to be "foolish optimism". According to V. Ross [3], director of strategy and risk for the UK's Financial Market Authority, "there is a long list of deviations from rational behavior which has been used to question the EMH”.

There have been several critical reviews of the EMH. One is the manifestation of "irrational exuberance" (a term first used by Federal Reserve Chair Alan Greenspan in 1996), which characterizes investors acting as if there is no uncertainty in the market, thus causing positive feedback. Another is contagion appetite, as evidenced and discussed in Philippas and Siriopoulos [31], where markets are prone to contagion effect because of "macroeconomic imbalances, sovereign risk perception and the arbitrage appetites" of internationally diversified portfolios. A third route of critic comes from behavioural finance. Kariofyllas et al. [32] and Philippas et al. [33] described herding behaviors, where empirical evidence shows the existence of over- and under-reaction in the capital markets. Finally, Lo [34] advanced the Adaptive Market Hypothesis under which market efficiency is a function of many factors and of the degree investors and market participants are adapted to changing market conditions, which is in line with the assumptions of rational expectations theory. Philippas and Siriopoulos [35] show that the adaptability of investors needs a short time to materialise because of market uncertainty and the deviations in pricing models in a given time period. 


\subsection{The Failure of the EMH and its Role in the Recent Crisis}

Nevertheless, in reality, the theoretical hypothesis of EMH is not true because due to noise, investors are unable to abstract all relevant information from market prices. Most of the research devoted to the recent financial crisis called the EMH responsible because of its role in the "chronic underestimation of the dangers of asset bubbles" by investors and regulators [1]. The reason is that regulators, analysts and investors felt too comfortable with market efficiency and they failed to detect any asset "bubble". Even sophisticated investors were overconfident about the risks involved in complex financial products and responded as connoisseurs to any financial innovation developed by the financial intermediaries and Fintech. Still, the ability of economic agents to make informed financial decisions, although critical to financial stability, and to contribute to more efficient allocation of financial resources, is problematic and calls for the coordination of financial education and regulators $[16,36]$. In this direction, Bernanke [7] noted that "the recent crisis demonstrated the critical importance of financial literacy and good financial decision-making, both for the economic welfare of households and for the soundness and stability of the system as a whole".

Fox [4] pointed out the remarkable admission of the former chair of the Federal Reserve, Alan Greenspan, that his trust in market efficiency and belief that financial markets are selfcorrecting and that therefore government regulation and supervision is not needed, were consistently wrong. In his testimony before the Parliamentary Committee on Government Oversight and Reform, Greenspan said that when the markets collapsed, he was "shocked" and that "the whole spiritual edifice collapsed" (p. xii). In Fox's [4] sharp summary, Greenspan accepted "that he had misunderstood how the world works" (p. xi). This "intellectual edifice" of Alan Greenspan is based on rationality and "market selfcorrection", which has been supporting the EMH for half a century now. If we take Greenspan's testimony as valid, the assumptions of rational expectations, with the associated notion that informational asymmetries vanish in equilibrium, are problematic in themselves and in their impact on the EMH, even if they "round off" the role of markets.

Alan Greenspan's conception and that of others also of course, of the market's ability to self-correct, so that regulation and supervision are not necessary, hastily contributed to the deregulation of markets and the financialization of economies. Regulators failed to realize that financial institutions, banks in particular, are culture-specific [11], and that the financial development of an economy is driven by financially literate investors especially under the Fintech advancements. This is particularly seen in developing countries and emerging markets, where regulatory measures are insufficient and financial literacy is quite weak. A result of the premature liberalization of markets and the effect of rashly removing regulatory restrictions, was the presence of, adverse selection (financial institutions allocate loans to applicants without screening, thus, they do not distribute credit efficiently) and moral hazard problems (financial institutions undertake greater risks without applying the required risk management practices) which further destabilized the financial system. Many studies have reported the high correlation between the pricing of credit with risk management and assessment [11].

In order to avoid sporadic and ad hoc regulatory actions as a response to a crisis which could well make future crises more probable and severe and could stifle financial innovation it would be preferable for effective regulation to focus on the specific source of the market failures and common features of financial crises. As noted by Ross [3], "the crisis has shown, for us regulators to sit back and rely purely on the market to avoid asset price bubbles does not work either". In other words, this short-term and myopic perception of market surveillance does not work. Besides the common characteristics of a financial crisis - financial asset bubble, credit flourishing, and capital inflows - the key role of financial regulators is investors' protection, and it should be for the benefit of the society that regulators would deal with the behavioural critiques of the EMH.

In fact, as former US President Barack Obama has argued "irresponsible actions on Wall Street and daily investment choices on Main Street" (Obama, April 2, 2010, para. 2) are the cause of the recent crisis [37]. This position supports a truth in the sense that the devaluation of financial assets is not caused by any natural catastrophe but by the actions of investors and the reactions of regulators in dealing with financial crises. In other words, we do not need to redefine the economy or demonize financial products and markets, as they do not exist without our actions.

\subsection{Financial Technology Risk}

Specifically, with the advance of financial technology innovation and in particular Fintech, it is expected an increase of the participation of less wealthy household and less financially educated investors into the financial markets [38]. Being able to have access to financial markets with low cost transactions and thus widening financial inclusion, apart from the expected benefits financial risk will rise as well. The financial inclusion process implies more intense competition between bank and nonbank providers insofar as the latter proliferate and emerge as the first financial alternative accessible to broad segments of the world's population [39].

This is mainly because Fintech and robo-advisors will decrease the fixed costs and increase the access to the markets, while big data availability will reduce the effectiveness of existing regulations. As a result, a higher systemic risk is expected, at least in the short term as it is difficult for regulators to respond in a timely manner. For example, Vives [40] argued that the banking industry is along the way of a more customer-centric approach, and that it will be up to the regulators to specify what level of protection will be afforded to customers and how to drive a balance between financial innovation and financial stability. Hence, the challenge for regulators is to maximize the benefits of Fintech while minimizing potential risks for the financial system. Finally, the financial inclusion route is not risk free as the financial 
implications should not be decoupled from the labor or educational and financial literacy dimensions [39].

On the other hand, regulation and financial innovation without investor improvement would not work. For instance, the complexity of complicated financial products makes them less attractive to financial illiterate investors, and if used by them minimizing the investment risk is not achieved. What could have a positive effect would be their synergy and complementarity. Besides that, however, even the combination of stringent regulations and more financially literate investors will not eliminate impending financial crises due to the continuity of financial innovations [35, 41]. Therefore, financially educated market participants will foster more appropriate risk, assessed financial innovations as a reaction to the many changes of the financial and regulatory architecture, and as a response to the continuous process of searching for low-cost financial instruments and transactions.

\section{FINANCIAL LITERACY AS A} RISK MANAGEMENT TOOL

\subsection{Complementarity of Regulators and Financial Education}

Irrational behavior may lead to investors taking decisions in contradiction to market logic and leading to huge losses. Recent research reports that individuals with higher levels of financial illiteracy tend to make more high-cost transactions, suffering higher fees and commissions and using high-cost products and methods of borrowing [17, 18, 36, 42]. A related research conducted by Agarwal, et al. [43] revealed a Ushaped pattern over the life- cycle, with the minimum amount of transactions fees, commissions and investment mistakes occurred at about age 53. Campbell [15] showed that individuals often do not understand the terms of their mortgages and committed major financial mistakes such as absence of diversification, lack of ability to choose the right financial instrument, and non-understanding of new financial tools and under-participation in financial markets, with important implications for financial innovation. Siriopoulos and Skaperda [18] analyzed the performance of 1-and 5-stars US mutual funds for the period 1981-2016 and reported that investors pay higher fees for gaining an almost the same return. This result is not in accordance with the rational expectations theory and may be attributed to investors' lack of financial knowledge.

According to Wikipedia, "Financial literacy is the possession of the set of skills and knowledge that allows an individual to make informed and effective decisions with all of their financial resources", while Mandell [44] defined financial literacy as "the ability of people to make financial decisions in their own best short- and long-term interests". The IOSCO Education and Training Team [45] identified the concept of "investor literacy" as the "understanding ordinary investors have of market principles, instruments, organizations and regulations." Conferring to Huston [46], "financial literacy (or financial knowledge) is typically an input to model the need for financial education and explain variation in financial outcomes" (p. 296) and has an application dimension, which implies "that an individual have the ability and confidence to use his/her financial knowledge to make financial decisions" (p. 307). Lusardi and Mitchell [16] considered "financial knowledge as a form of investment in human capital" that can be used to improve welfare through better decision making and mitigate systemic risks.

In sum, irrational behaviour and financial illiteracy lead to investment decisions that are not in accordance with the EMH, especially when they have to deal with structured financial products that are too complex even for professional institutions to understand. Haldane [47] offered as an example that an investor in CDO needs to read and understand around 200 pages, in ABS CDO 30,300 pages, and in CDO2 more than 1,000,000 pages. Subramanian [11] went further, saying that "much of it was not comprehended by bankers and their executive officers". This is because investors adopt innovative financial instruments without having prior knowledge, "just to be ahead of the game" [35].

On the other side, investors' protection and market confidence are two of the major concerns for financial regulators. Thus, the benefits and responsibilities of financial regulation and financial education go hand in hand and should work in parallel with one another. They interact. In particular, financial education and financial literacy can be viewed as an "additional tool available to securities regulators in supporting regulation and supervision" [45], which could more effective achieving the objective of investors' protection. Lusardi and Mitchell [16] stated that "financial regulation and financial education are not necessarily substituting, as they can also complement each other". In addition, financial education can play an important role in consolidating financial market regulation. Informed investors not only protect their investments, but also comply better with regulatory rules. In other words, financial illiteracy could be considered as a systemic risk factor.

Financial education has also preoccupied politicians, especially since the 2008 crisis, as a possible solution to other impending crises. For example, Canadian Finance Minister Jim Flaherty acknowledged in a 2009 speech that "the recent financial crisis has been fueled by a lack of financial education". Furthermore, the OECD noted that "financial education has gained international recognition ... more and more countries are developing adapted financial education strategies and programs, introducing financial education into the curriculum and designing specific learning contexts" [48]. In addition, the International Organization of Securities Commissions (IOSCO), in a recent Consultation Report [45] underlined the importance of investor education and emphasizes the role of financial literacy in the functioning of the financial markets. In this report, the IOSCO also indicated that investor education and financial literacy programs should be supported by national securities and exchanges commissions. In fact, the report underscored the value of such programs as enhancing human capital investment, describing them as important tools in the hands of financial regulators in 
supporting their efforts toward market supervision and investors' protection, because they "can help address any misalignment of investor and industry interests, particularly with respect to information asymmetry" [45].

Obviously, there is a strategic complementarity between regulators and financial education. As our capitalistic economy is increasingly financialized, and everything including the real economy is acting like a financial market, regulators' strategic motivation to use investor education and financial literacy programs as a systemic risk management tool in preventing potential financial bubbles and panics has become more important in recent years [49]. As of today, there are numerous financial literacy programs offered by public agencies. For instance, Bernanke [7] reported that Federal Reserve Banks, through their Community Affairs offices, have developed various financial education materials and programs covering a series on topics that range from establishing banking accounts to building wealth. In its 2014 report on the investor education websites, IOSCO [45], several examples from various countries of IOSCO members are also reported.

\subsection{The Opportunity Cost of the Financial Education}

The recent financial crisis raised another important question regarding the awareness of investors (private and institutional) of the asset bubble that led to the crisis. It is logical to ask whether investors did not consider the possibility of a stock market bubble, given that their behavior seemed to indicate an expectation that prices would continue to increase, and that assets were thus priced incorrectly. In particular, the question arises: How was it possible for investors- if they were rational, believed in the EMH, and had access to low-cost information not to discern the asset bubble, in spite of all the evidence provided by orthodox academic studies suggesting passive management and index investment [2]? The orthodox view that, prices discount everything completely and immediately has no basis in fact. Also, as Gromb and Vayanos [50] noted, there is no explanation as of why the arbitrage strategies fail to adjust rapidly the prices to their fundamental values. An obvious answer is that financial instruments and market mechanisms and conditions are so complex that no investor even professional and sophisticated ones - can understand the changes and adapt instantaneously.

Simon [51] showed that "bounded rationality" directs complex decision processes. Thus, markets are not efficient because investors cannot optimize. As a result, markets are necessarily inefficient, and equilibrium models (such as the Capital Asset Pricing Model, CAPM) are conditionally correct. Assuming that investors are bounded rational, they prefer to replace the complexity of markets with a business-manageable model capable of leading to an investment decision in a reasonable time. This is precisely the spirit of simplifying heuristic behaviour: "substitution of the less complex for the intractable" [52]. In other words, such behaviour follows heuristic rules such as technical indicators, fundamental analysis, herding or even, more recently, simplistic artificial intelligence methods. This also means that there is less demand for financial innovative products and markets because people do not understand their use and terms, and their value. Herding behavior is also observed, where investors are acting in concert without adequate knowledge and appreciation of risk/reward trade-offs. Herding aggravates market volatility and increases the fragility of the financial system [5]. Naive and less financially literate investors "subsidize the costs of more sophisticated financial products for those who can use them appropriately" [15]. Thus, financial illiteracy increases financial mistakes, has well-being implications for the investors and households, and reduce the value of financial innovation.

Many researchers today believe that the recent economic crisis illustrated the cost of financial illiteracy. According to Lussardi and Mitchell [16] "if the effects of financial literacy on financial behavior can be taken as causal, the costs of financial ignorance are substantial". In addition, recent research has provided evidence of a strong correlation between financial education and a set of investment behaviors and showed that financial mistakes are more frequent among the young and less educated people [36].

Due to the bounded rationality of human beings, investing in financial education reduces the likelihood of a severe future systemic crisis. Yet saving this investment and transferring the capital to another activity is also not certain to bring the expected benefit. Thus, the opportunity cost of not investing in financial education is high as it increases the likelihood of a sudden future financial crisis. Therefore, a convex combination of regulators and financial education may benefit markets and society.

Convex payoffs benefit from uncertainty and extreme events. The nonlinear properties of a convex payoff function offer the opportunity to formulate rational and rigorous policies, and ones that allow investors to take advantage of volatile and uncertain markets. The more convex the payoff function, expressed in the difference between potential rewards and losses, the larger the convexity bias. This means that the difference between the expected benefits of sporadic and ad hoc regulatory measures aftermath the crisis (which is the linear case where benefits and failures are equal), and one in which benefits and losses are asymmetric (which is the case of a convex payoff function) is greater. And as the financial environment is volatile and uncertain, the higher the convexity bias will be.

\section{DISCUSSION AND CONCLUSION}

The role of the EMH and consequently of regulators and investors in the recent crisis is not insignificant. Belief in a problematic issue such as the EMH, both for investors and regulators, underestimated the risks of high volatility and soaring asset prices. Financial literacy supports investor education and can work with regulators to protect against future crises. However, even the most effective market regulation combined with the best financial education of investors, will not be able to eliminate future financial crises. 
In our opinion, there are two reasons which explain this statement. The first is that investors' preferences are convex, in the sense that investors prefer high volatility and risk, as opposed to the case of rational expectations, where investors dislike risk. The second reason has to do with the real economy and financial capitalism, which at times when returns are small and therefore prices high leads to the devaluation of financial assets. There is a fundamental flaw in the economy of capitalist financial institutions, no matter how smart and insightful investors may be, the speculative and innovative elements of capitalism will eventually lead to financial uses and relationships that lead to instability [54]. That is, programs on investors education and financial literacy should be comprehensive, not only to acquire and generate knowledge about existing markets and its present regulatory characteristics, but also "to reflect on the effects and complexity of behaviors and decisions from a responsible, global and future-oriented perspective" [55].

Finally, we believe that investor education, is a complex and multifaced task and understanding financial markets one has first to consider the economic mechanisms underneath. In order to be able to help effectively, should be comprehensive and not focus solely on knowledge and calculation of the characteristics of the distribution of assets under the EMH and the model of rational expectations, and to the myopic pricing models. All economic agents in general and financial investors in particular should be aware of the functioning not only of the securities markets but also of the mechanisms of our capitalistic system and the limitations of its ongoing financialization.

In addition, financial education can play an important role in consolidating financial market regulation. Informed investors not only protect their investments, but also comply better with regulatory rules. Financial industry and financial innovation will also benefit. In fact, as has been shown by Philippas and Siriopoulos [35], a financial innovation does not always add value by making financial intermediation available to all economic agents who can effectively use it by reducing transaction costs and by making the market more attractive [35]. These findings cannot happen, unless investors are financially literate and educated. Therefore, financially educated market participants will lead to more appropriate risk-assessed financial innovations along with low cost financial instruments and transactions.

In this paper we discussed the role of financial literacy as a systemic financial risk management tool. We first discussed the role of the efficient market hypothesis in the recent financial crisis and the strong belief of regulators in its assumptions. We argued that overconfident to the market efficiency hypothesis in combination with financial illiteracy increased the financial systemic risk.

Our analysis suggests that this combination generated bubbles in financial assets return and that this momentum effect was likely to be strongest in those markets whose interpretation of ambiguous financial information was required. Actions to implement financial education programs would contribute to strengthened financial systems, to environments conductive to financial innovation, and to more rational risk taking. Consistent with this analysis, systemic risk is stronger in markets where financial illiteracy is higher.

\section{REFERENCES}

[1] Nocera, J. (2009). Poking Holes in a Theory on Markets, New York Times, New York Times business column, June 5, 2009.

[2] Ball, R. (2009). The Global Financial Crisis and the Efficient Market Hypothesis: What Have We Learned? Journal of Applied Corporate Finance, 21(4), pp. 8-16.

[3] Ross V. (2009). UK's Financial Services Authority: Efficient Markets and Market Regulation. Speech by Verena Ross, Director of Strategy and Risk, Chartered Financial Analysts Annual Conference, 18 June 2009.

[4] Fox, J. (2011). The myth of the rational market: A history of risk, reward, and delusion on Wall Street. Harper Business.

[5] Colander, D., Föllmer, H., Haas, A., Goldberg, M. D., Juselius, K., Kirman, A., Lux, T., \& B. Sloth. (2009). 'The Financial Crisis and the Systemic Failure of Academic Economics.' Discussion Paper No. 09/03, Department of Economics, University of Copenhagen.

[6] Brown, S. J. (2020). The Efficient Market Hypothesis, the Financial Analysts Journal, and the Professional Status of Investment Management. Financial Analysts Journal, 76(2), pp. 5-14.

[7] Bernanke, B. (2011). Financial literacy, Statement by Mr Ben S, Chairman of the Board of Governors of the Federal Reserve System, Subcommittee on Oversight of Government Management, the Federal Workforce, and the District of Columbia, Committee on Homeland Security and Governmental Affairs, US Senate, Washington DC, 20 April 2011.

[8] SEC (2012). Study Regarding Financial Literacy Among Investors: As Required by Section 917 of the Dodd-Frank Wall Street Reform and Consumer Protection Act (2010).

[9] Perry, V.G. (2008). Is ignorance bliss? Consumer accuracy in judgments about credit ratings. The Journal of Consumer Affairs, 42(2), pp. 189-205.

[10] Driver, T., M. Brimble, B. Freudenberg, and K. Hunt (2018). Insurance literacy in Australia: Not knowing the value of personal insurance, Financial Planning Research Journal, 4(1), pp. 53-75.

[11] Subramanian, K. (2010). Efficient Market Hypothesis: The model that failed, Economic and Political Weekly, 45(31), pp. 20-22.

[12] Krugman, P. (2009). How did economists get it so wrong? New York Times, 6 September.

[13] Gerrans, P., Clark-Murphy, M. and Truscott, K. (2009) 'Financial literacy and superannuation awareness of indigenous Australians: Pilot study results', Journal of Social Issues, 44(4), pp. 417-439.

[14] Easterlin, R. A. (2006). Life cycle happiness and its sources: Intersections of psychology, economics, and demography, Journal of Economic Psychology, 4(27), pp. 463-482.

[15] Campbell, J. (2006). "Household Finance." NBER Working Paper, No 12149. 
[16] Lusardi, A., and O. S. Mitchell (2014). The Economic Importance of Financial Literacy: Theory and Evidence, Journal of Economic Literature, 52(1), pp. 5-44.

[17] Barber, B.M., D. Terrance, Lu Zheng (2005). Out of Sight, Out of Mind: The Effects of Expenses on Mutual Fund Flows, Journal of Business, 78(6), pp. 2095-2119.

[18] Siriopoulos, C., and M. Skaperda (2020). Investing in mutual funds: are you paying for performance or for the ties of the manager?, Bulletin of Applied Economics, 7(2), pp. 1530164.

[19] Blue, L., and M. Brimble (2015). A holistic approach to financial literacy education.

[20] Delcey, T. (2019). Samuelson vs Fama on the Efficient Market Hypothesis: The point of view of expertise, OEconomia, 9(1), pp. 37-58.

[21] Sharpe, W. F. (1970). Stock Market behavior: A discussion, Journal of Finance, 25(2), pp. 418-420.

[22] Beaver, W. (1981). Market Efficiency, The Accounting Review, 56(1), pp. 23-37.

[23] Jensen, M. (1978). Some Anomalous Evidence Regarding Market Efficiency, Journal of Financial Economics, 6(2-3), pp. 95-101.

[24] Thaler, Richard H.; Sunstein, Cass R. (2008). Nudge: Improving Decisions about Health, Wealth, and Happiness. Yale University Press.

[25] Cowles, A., and H.E. Jones (1937). Some a posteriori probabilities in stock market action. Econometrica, 5(3), pp. 280-294.

[26] Mills, T.C., C.Siriopoulos, R.N.Markellos, D.Harizanis (2000). Seasonality in the Athens Stock Exchange, Applied Financial Economics, 10(2), pp. 137-142.

[27] Siriopoulos, C. and L. Youssef (2019). The January barometer in emerging markets: new evidence from the Gulf Cooperation Council stock exchanges. Investment Management and Financial Innovations, 16(4), 61-71.

[28] Hsieh, D. A. (1991). Chaos and Nonlinear Dynamics: Application to Financial, Markets, Journal of Finance, 46(5), pp. 1839-1877.

[29] Siriopoulos, C. (1996). Investigating the behaviour of mature and emerging capital markets, Indian Journal of Quantitative Economics, 11(1), pp. 78-98.

[30] Sewell, M. (2012). The Efficient Market Hypothesis: Empirical Evidence. International Journal of Statistics and Probability; 1(2), pp. 164-178.

[31] Philippas, D., and C. Siriopoulos (2013). Putting the "C" into crisis: Contagion, correlations and copulas on EMU bond markets, Journal of International Financial Markets, Institutions and Money, 27, pp. 161-176.

[32] Kariofyllas, S., D. Philippas, and C. Siriopoulos (2017), "Cognitive biases in investors' behaviour under stress: Evidence from the London Stock Exchange", International Review of Financial Analysis, 54, pp. 54-62.

[33] Philippas, D., Philippas, N., Tziogkidis, P., RIBA , H. (2020) Signal- herding in crypto currencies. Journal of international financial markets institutions and money, 65, pp. 1-16

[34] Lo, A.W., (2004). The Adaptive Markets Hypothesis, The Journal of Portfolio Management, 30 (5), pp. 15-29.
[35] Philippas, D., and C. Siriopoulos (2012). Is the progress of financial innovations a continuous spiral process?", Investment Management Financial Innovations, 9(1), pp. 20-31.

[36] Klapper, L. F., A. Lusardi, and G. A. Panos (2012). Financial Literacy and the Financial Crisis, NBER Working Paper No. 17930, March.

[37] Arthur, C. (2012). Financial Literacy Education Neoliberalism, the Consumer and the Citizen, Sense Publishers, The Netherlands.

[38] Philippon, T. (2020). On fintech and financial inclusion. BIS Monetary and Economic Department, Working Papers No 841, February.

[39] Valverde, S.C., and F.R. Fernandez (2020). Financial digitalization: banks, fintech, bigtech, and consumers, Journal of Financial Management, Markets and Institutions, 8(1), pp. 1-13.

[40] Vives, X. (2019). Digital disruption in banking, Annual Review of Financial Economics, 11, pp. 243-272.

[41] Waller, K. (2009). Innovation and the Financial sector: Role of the Asia-Pacific economic cooperation, In Fan, Q., K. Li, D.Z. Zeng, Y. Dong, and R. Peng (eds.) Innovation for development and the role of government: A perspective from the East Asia and Pacific region. The World Bank, pp. 103-121.

[42] Lusardi, A. and P. Tufano (2009). Teach Workers about the Perils of Debt. Harvard Business Review, November.

[43] Agarwal, S., J. Driscoll, X. Gabaix, and D. Laibson (2009). “The Age of Reason: Financial Decisions over the Life-Cycle with Implications for Regulation." Brookings Papers on Economic Activity, 2.

[44] Mandell, Lewis (2008). "Teaching Young Dogs Old Tricks: The Effectiveness of Intervention in Pre-High School Grades." In Financial Literacy for Children and Youth, edited by Thomas A. Lucey and Kathleen S. Cooter, pp. 221-236. Athens, GA: Digitaltextbooks.biz LLC.

[45] IOSCO (2014). Strategic Framework for Investor Education and Financial Literacy. CR03/14, May.

[46] Huston S. J. (2010). Measuring Financial Literacy, The Journal of Consumer Affairs, 44(2), pp. 296-316.

[47] Haldane,A. G. (2009). Rethinking the financial network. Speech by Andrew Haldane, Executive Director, Financial Stability, Bank of England, delivered at the Financial Student Association, Amsterdam, 28 April 2009.

[48] OECD. (2011). Guidelines on financial education at school and guidance on learning framework (final draft for public consultation).

[49] Krugman, P. "Out of the Loop." New York Times, March 4, 2001, Sec. 4, p. 15.

[50] Gromb D., Vayanos D. (2010). Limits of arbitrage: the state of the theory, the Paul Woolley center working paper series No 9, Discussion Paper No 650.

[51] Simon, H. A. (1982). Models of bounded rationality. Cambridge, MA: MIT Press.

[52] Hawawini, G., and D. Keim (1995). On the Predictability of Common Stock Returns: World-Wide Evidence, In R. Jarrow et al., Eds., Handbook in OR and MS, Vol. 9, Chapter 17, pp. 497544, Elsevier.

[53] Bikhchandami, S., and S. Sharma (2000). Herd behavior in financial markets: A Review. International Monetary Fund, WP $/ 00 / 48$ 
[54] Minsky (1977). "Banking and a Fragile Financial Environment." Journal of Portfolio Management 3(4), summer.

[55] Barth, M.; Godemann, J.; Rieckmann, M.; Stoltenberg, U. (2007). Developing key competencies for sustainable development in higher education. Int. J. Sustain. High. Educ., 8, 416-430.

$\begin{aligned} & \text { CC) } 2020 \text { by the Costas Siriopoulos. Submitted } \\ & \text { for possible open access publication under the } \\ & \text { terms and conditions of the Creative }\end{aligned}$
$\begin{aligned} & \text { Commons } \\ & \text { (http://creativecommons.org/licenses/by/4.0/). }\end{aligned}$

